\title{
E-HEALTH IN THE CONTEXT OF THE SUBSIDIARITY PRINCIPLE. COMMENTS AGAINST THE BACKGROUND OF POLISH LAW
}

\author{
Leszek Sobieski*
}

\begin{abstract}
In the article an attempt was made to present the assumptions of Polish legislative solutions concerning e-health in the context of one of the basic principles of European philosophical and legal thought - the principle of subsidiarity. The principle of subsidiarity, the essence of which is to leave it to the political communities to carry out tasks for which they can take responsibility, has been incorporated into the legislation of nation states and the European Union, determining the identity of European civilisation.

Article 5 of the Treaty on European Union and the Treaty on the Functioning of the European Union and the preamble to the Constitution of the Republic of Poland are an example of the translation of the subsidiarity principle into legal norms. Attention has been paid to the possibility of decentralising and delegating competences to lower levels of public authority in the field of health, using or amending the e-health legislation accordingly. Appropriate division of tasks and competences in the area of health care, taking into account the subsidiarity principle, can be observed at both national and EU level. European Union law recognises the autonomy of the Member States to define national health regulations. On the basis of selected national and EU regulations, a definition of e-health has been proposed, understood as a set of provisions within the health care system regulating the collection, processing of data and provision of health care services in order to identify and optimise the satisfaction of individual and collective health needs as well as to pursue an effective health policy by public authorities. The basic assumptions of key national and EU legal acts are also indicated. On the basis of the solutions adopted in the Act on Health Care Services Financed from Public
\end{abstract}

MA, Department of Public Business Law, Faculty of Law and Administration, The Adam Mickiewicz University in Poznań. 
Funds, the formal possibility of delegating and effective performance of tasks has been demonstrated in the field of health protection by local government units. New information and communication technologies provide the basis for a more complete implementation of the subsidiarity principle in health protection, as they enable the necessary knowledge on the collective and individual health needs at European, national and any other expected level - regional, population, age to be gathered and transferred. They are a tool, previously unavailable, for the precise identification of the needs of separated communities. On the other hand, new technologies can be a tool for communities to meet these needs to the extent that they are able to provide organisational and financial security. The combination of new information and communication technologies with the application of a systematic concept of tasks implementation based on the principle of subsidiarity will allow for a change in the model of health care in Poland.

Key words: subsidiarity principle, e-health, health care

\section{INTRODUCTION}

In European philosophical and legal thinking, the attribute of immutability is reserved exclusively for divine law and the laws of nature. Montesquieu points out that the purpose of the law of human communities is to strive for the good, the material scope of which changes under the influence of the place, time and circumstances in which the community exists ${ }^{1}$. The law in force at a given time is a response to changes which, apart from the development of societies and economic changes, are also influenced by the development of technical culture. Technological changes should not be an end in themselves, but their function is to be a useful instrument for the implementation of previously adopted assumptions, e.g. concerning the organisation of the state commonwealth. The question arises to what extent well-established principles - political concepts are valid in political commonwealths, permeated by technological changes. Is it legitimate to assume that the principle of subsidiarity determines the scope and direc-

1 See: Charles Montesquieu, The Spirit of Laws, Book XXVI, Of Laws, as relative to the order of things on which they determine. Chapter II. Of Laws divine and human, Warsaw: F. Hoesick, 1927. 
tion of the use of modern technologies? The issue of eHealth seems to be a good illustration for deliberations in this area.

The combination of the principle of subsidiarity, which, in the doctrine of law and philosophy, has an established meaning and area of application, with the issue of modern information and communication technologies seems legitimate in the context of the challenges of the present day. It is beyond the scope of this article to academically demonstrate the basic issues currently faced by health care systems in European countries, especially in Poland. It should be assumed that each health care system must solve the following issues: availability of those entitled to health care services, organisation of health care services and covering the costs of system operation. These are challenges which, regardless of the potential that a political community has, must find real and legislative solutions. The issues of financial efficiency of the health care system and the quality of services provided are matters that are in the focus of interest of the medical community and society. Postulates are formulated to use new technologies to construct a new model of health care. The challenges faced by societies and public authorities in relation to e-Health issues of scientific interest. The literature of the subject analyses selected aspects of the application of new technologies, from the issue of organising the provision of health services with the use of innovative solutions, to securing the rights of the individual - the patient functioning in the reality of digital technologies ${ }^{2}$. Part of the available literature focuses on communication and information and communication technologies and solutions (hereinafter 'ICT') for health management and health care applications, in particular on new ICT to reduce costs and improve the quality of health care. Another research current related to ICT solutions in health care includes technical topics, where available applications and their implementations for health care systems are examined, as well as analyses concerning the design, implementation and management of communication technologies, in order to increase the efficiency of the operation of medical entities. Another research trend is the analysis of ethical, legal and regulatory issues related to ICT in health care. And it is in this current that this article is found, the aim of which is

2 Antonio Gaddi, Fabio Capello, Marco Manca, eHealth, Care and Quality of Life, Springer Science \& Business Media, 2013, 220. 
to draw attention to the use of new technologies against the background of a single principle of subsidiarity in the context of national law, of which European Union law is a part.

\section{SUBSIDIARITY PRINCIPLE}

One of the recognized concepts of legal and social order arrangement is the principle of subsidiarity. It is presented in the encyclical Pius XI Quadragesimo anno $(\ldots)$ it is true that on account of changed conditions many things which were done by small associations in former times cannot be done now save by large associations. Still, that most weighty principle, which cannot be set aside or changed, remains fixed and unshaken in social philosophy: Just as it is gravely wrong to take from individuals what they can accomplish by their own initiative and industry and give it to the community, so also it is an injustice and at the same time a grave evil and disturbance of right order to assign to a greater and higher association what lesser and subordinate organizations can do. For every social activity ought of its very nature to furnish help to the members of the body social, and never destroy and absorb them. The supreme authority of the State ought, therefore, to let subordinate groups handle matters and concerns of lesser importance, which would otherwise dissipate its efforts greatly. Thereby the State will more freely, powerfully, and effectively do all those things that belong to it alone because it alone can do them: directing, watching, urging, restraining, as occasion requires and necessity demands. Therefore, those in power should be sure that the more perfectly a graduated order is kept among the various associations, in observance of the principle of "subsidiary function," the stronger social authority and effectiveness will be, the happier and more prosperous the condition of the State. The principle presented in the encyclical almost ninety years ago has been developed in European Community law and national law. It has become the official principle governing the function-

3 See: Pius XI, Encyclical on re construction of the social order on the 40th anniversary of the encyclical Rerum Novarum, Warsaw: Katolickie Towarzystwo Wydawnicze, 1932. 
ing of the European Union ${ }^{4}$. It means that the European Union is to act in the interests of the Member States when a given country is not a able to carry out specific tasks on an individual basis. The activities of the Union are to be complementary to those of the Member States 5 . In Polish law, the principle of subsidiarity is ${ }^{6}$ literally expressed in the preamble of the Constitution of the Republic of Poland ${ }^{7}$ of 2 April 1997 and its individual provisions ${ }^{8}$. In the Constitution, this principle is implemented through the decentralisation of public authority and public finances in favour of local government units - 15(1), Article 16(2), Article 163, Article 164(3), Article 167, (1) and (4). The interpretation of this principle is provided by the case-law of the Constitutional Tribunal. In the opinion of A. Dobek ${ }^{9}$, the jurisprudence of the Constitutional Tribunal leaves no doubt that the principle of subsidiarity in the Polish legal system is a model of oversight over the constitutionality of legal acts, which first of all means that it indicates the direction of action of the legislator and the adjudicating bodies. The author refers to individual judgments which confirm the accuracy of this thesis. In the judgment of 8 May 2002 (K 29/00), the Constitutional Court states that the principle of subsidiarity is a "constitutional directive on the definition of the tasks and powers of

4 Article 5 of the Treaty on the European Union and the Treaty on the Functioning of the European Union, consolidated version; Official Journal of the European Union 2010/C 83/01.

5 Tomasz Musialik, „Stosowanie zasady pomocniczości na gruncie traktatu z Lizbony”, Modern Management Review 4(2013): 147-148.

6 See more: Manfred Spieker, "Subsidiarity principle: anthropological foundations and political consequences", Społeczeństwo 1(1995): 35-37; Ewa Popławska, "Effect of the principle of subsidiarity on system chan ges in Poland”, In: Subsidiarity, ed. Dariusz Milczarek, Warsaw: Centrum Europejskie Uniwersytetu Warszawskiego, 1998, 138-139; Michał Kulesza, "Principle of subsidiarity as a key to the reform of the administrative system of Central and Eastern European countries (using Poland as an example)", In: Subsidiarity...., 125-126.

OJEU. No. 78, item 483.

8 Bogusław Banaszak, Constitution of the Republic of Poland. Commentary, Warsaw: C.H. Beck, 2009.

9 More: Agnieszka Dobek, "Subsidiarity principle in the jurisprudence of the Constitutional Court", Państwo - koncepcje i zadania, Studia Erasmiana Wratislaviensia, Vol. III (2008): $155-168$. 
public authorities and on the distribution of tasks among them as such". In the judgment of 7 December 2005 (Kp 3/05) the Constitutional Tribunal ruled that the principle of subsidiarity is the basis for defining the essence of public tasks, for distributing these tasks between local government and the state. In its judgments, the Constitutional Tribunal takes into account the dynamic nature of the principle of subsidiarity. In its opinion, depending on the situation, there should be a shift of competencies either upwards or downwards. The Tribunal often points out that the principle of subsidiarity must be understood in all its complexity and stresses that when quoting the principles of law one must take into account all the values invoked in the Constitution as well as the whole of a given case (K 24/02, U 5/04). Therefore, it should be assumed that the principle of subsidiarity defines the systemic framework of the state, within the scope of which, as a rule, public tasks should be delegated to the lowest possible level, in accordance with the organisational and financial capabilities of individual communities (local government units).

\section{E-HEALTH - AN ATTEMPT AT DEFINITION}

The European Union builds its development policy on the basis of public health priorities, recognising that it is the health of the population that shapes social and economic life. Provisions on public health are contained in Article 168 of the Treaty on the Functioning of the European Union (hereinafter "TFEU"). This is the only provision of Title XIV 'Public Health' in Part Three of the TFEU, which means that health policy is an autonomous EU policy. Due to the existing treaty limitations and the increasing complexity of health relations, soft forms of coordination and support are becoming increasingly important in public health ${ }^{10}$.

E-health is a concept related to health care. Under European Union law, the concept of e-health is included in Article 14 of Directive 2011/24/ EU of the European Parliament and of the Council of 9 March 2011 on the application of patients' rights in cross-border healthcare (hereinafter re-

10 Iwona Wrześniewska-Wal, „Zdrowie publiczne w regulacjach Unii Europejskiej”, Postępy Nauk Medycznych, 5(2016): 322-326. 
ferred to as "Directive"). This concept is not defined synthetically in the Directive. The Directive only indicates the objectives to be achieved as part of e-health. This directive states that the European Union shall support and facilitate cooperation and the exchange of information between Member States acting within the framework of a voluntary network bringing together the national authorities responsible for e-health designated by the Member States. According to the directive, the formal IT network connecting the member states is to aggregate and make available data on health services provided and their beneficiaries, to the extent necessary for cross-border care.

In addition, according to the Directive, the objectives of the e-health network are activities aimed at generating sustainable economic and social benefits for European e-health systems and services and interoperable applications in order to achieve a high level of trust and safety, increase continuity of care and ensure access to safe, high-quality healthcare. The aim is also to draw up guidelines for a non-exhaustive list of data to be included in the patients' files and which can be exchanged between health professionals in order to ensure continuity of care and patient safety across borders and effective methods of making medical information available for public health and research purposes and to support Member States in the development of common means of identification and authentication to facilitate data portability in cross-border healthcare. The Directive "recognises" the fact that there is a wide variety of health systems in the Union and the incompatibility of information formats and communication technologies standards - hereafter "CTS" - used in healthcare provision, which constitutes an obstacle to cross-border healthcare provision and creates a potential risk to health care effectiveness ${ }^{11}$. Interestingly, in the context of this Article, the European Union accepts that the introduction and development of the CTS systems in healthcare belongs to national competencies. The Directive therefore recognises the importance of actions in the area of interoperability and competence sharing, enabling the Commission and the Member States to work together to develop measures which, although not legally binding,

11 See more: Namysły nad problemami polityki zdrowotnej globalnej - europejskiej - krajowej: księga jubileuszowa prof. dra hab. Cezarego W. Włodarczyka, ed. Iwona Kowalska, Anna Mokrzycka, Warsaw: Diffin, 2013. 
are supplementary tools at the disposal of the Member States to facilitate greater interoperability of the CTS systems in healthcare and to increase patients' access to e-health applications if the Member States decide to introduce them ${ }^{12}$. With regard to the interoperability of e-health services, the Directive calls for this to be achieved with due regard for national regulations on the provision of healthcare ${ }^{13}$.

Before attempting to present a definition of the concept of e-health, it is appropriate to look at national regulations on the use of CTS for the processing of healthcare data ${ }^{14}$. Under Polish law, the key role in this respect is played by the Act of 28 April 2011 on the Information System in Health Care ${ }^{15}$. The Act has been in force since 1 January 2012 and introduces the concept of an information system in health care. According to the Act, the purpose of this system is to process data necessary to pursue the state health policy, to improve the quality and availability of health care services and to finance health care tasks. According to the Act, the system created on its basis is to be of a universal nature and is to include medical entities and other entities obliged under the Act to process data in the field of health protection. The exclusions from the system apply to medical entities for persons deprived of their liberty providing medical services on the basis of Article 102(1) and Article 115(1) of the Executive Penal Code Act of 6 June $1997^{16}$ and medical entities operating in the form of a military unit within the meaning of Article 2(1)(1a) of the Act of 15 April 2011 on Medical Activity ${ }^{17}$. The Polish Act, like the EU regulations, adopts the method of indicating the objective and tasks to

12 More: Commission of The European Communities, Background document for press pack. Launch of Commission Communication Solidarity in health: Reducing health inequalities in the EU, 20.10.2009, Brussels, http://ec.europa.eu/health/ph_determinants/ socio_economics/documents/com2009_background_en.pdf.

13 See: recital 10, recital 50, recital 56, recital 57 of Directive 2011/24/EU of the European Parliament and of the Council of 9 March 2011 on the application of patients' rights in cross-border healthcare and Article 14 of the Directive.

14 More on the state of computerization Poland: Outline of the health care system, Health Systems in Transition, Vol. 13, 8(2011): 127 et seq.

15 Consolidated text Journal of Laws of 2017, item 1845.

16 Consolidated text Journal of Laws of 2018, item 652.

17 Consolidated text Journal of Laws of 2018, item 2190, as amended. 
be carried out with the use of CTS technology, without directly defining the notion of a system. At this point, it is worth noting one of the tasks of the information system being developed, i.e. support for the health policy of the state. The state health policy is a broad concept, which includes a number of concepts with a specific content in the legal language. One of these is the notion of health programme and health policy programme. Pursuant to Article 48(1) of the Act of 27 August 2004 on Health Care Services Financed from Public Funds ${ }^{18}$, health programmes may be developed, implemented, pursued and financed by the National Health Fund, and health policy programmes may be developed, implemented, pursued and financed by ministers and local government units. The Fund implements health policy programmes commissioned by the minister competent for health. The programmes referred to in that provision concern, in particular, important epidemiological phenomena; other significant health problems affecting the whole or a specific group of beneficiaries, with the existing possibilities of eliminating or reducing these problems and implementing new medical procedures and prophylactic measures. The Act reserves the requirement of coherence of individual programmes, as it stipulates that health policy programmes developed, implemented, pursued and financed by local government units, where they concern guaranteed benefits covered by programmes implemented by ministers and the Fund, must be consistent with them in terms of their content and organisation. The duration of a given programme is one-year or an indefinite period, since the statutory term 'several years' should be understood in this way. The health programmes are complemented by drug programmes, which will not be presented here.

This cross-section of selected provisions makes it possible to propose a synthetic definition of e-health. E-health is understood as a set of legal regulations within the health care system regulating the collection, processing of data and provision of services related to health care in order to identify and optimise the satisfaction of individual and collective health needs as well as to conduct effective health policy by public authorities. Such a definition makes it possible to discuss both the issue of so-called personalised medicine based on e-health and considerations in the context

18 Consolidated text Journal of Laws of 2018, item 1510, as amended. 
of actions taken on a larger scale using the assumptions of e-health. The latter of the issues identified will be addressed later.

\section{IMPACT OF THE SUBSIDIARITY PRINCIPLE ON THE USE OF E-HEALTH SOLUTIONS}

The Act of 27 August 2004 on Health Care Services Financed from Public Funds defines one of the tasks of a local government unit (hereinafter referred to as "l.g.u.") in the area of meeting the needs of the local government community, which is the financing of health care services. The legislator's intention expressed in this Act is not only to secure the financing of health care services, within the meaning of accepting payment for the services provided, but actual organisation of access to services for members of the local government community. The Act uses the term "guaranteed services" to describe the services covered by the activities of the l.g.u. Article 5 of the Act defines the notion of guaranteed services as health care services financed in full or co-financed from public funds according to the rules and within the scope specified in the Act. Based on the content of the Act on Health Care Services Financed from Public Funds and the lack of a separate definition, it should be assumed that the synonym of "health care services" is the term defined in the Act as "health care services", understood as activities aimed at prevention, preservation, rescuing, restoring or improving health and other medical activities resulting from the treatment process or separate provisions regulating the rules of their provision. Article 9a of the Act on Health Care Services Financed from Public Funds indicates the formal framework in which the actions of the l.g.u. should be embedded when taking organisational measures to secure access to guaranteed services. The local government unit does not have the possibility to arbitrarily decide which services should be financed from the public funds in its possession. The reason for such an assumption is the discrepancy between the needs in the area of health protection and real financial possibilities. In order to determine the rationalisation of the scope of l.g.u. intervention, official documents - the regional map of health needs and the priorities adopted for the regional health policy are used, complemented by l.g.u.'s findings as to the state of access to health care services 
in the region. Pursuant to Article 95a of the Act on Health Care Services Financed from Public Funds, a Regional Health Needs Map is prepared for the area of the voivodeship, taking into account the specific health needs of the region's (voivodeship's) community. The Regulation of the Minister of Health of 26 March 2015 on the scope of the content of health needs maps ${ }^{19}$ defines what the "map" should include. According to this regulation, the Regional Health Needs Map and the All-Poland Health Needs Map consist of demographic and epidemiological analysis, analysis of the state and use of resources, health needs forecasts. On the other hand, the national list of health policy priorities is defined in the Regulation of the Minister of Health of 27 February $2018^{20}$ on health priorities, enacted on the basis of Article 31a(2) of the Act on Health Care Services Financed from Public Funds. The list includes 10 key priority areas of health policy. On the basis of Article 95c of the Act on Health Care Services Financed from Public Funds, the governor acting in consultation with the Voivodship Council for Health Needs, sets the priorities for the regional health policy, taking into account the state of health of citizens and the attainment of health effects of the highest value.

The regulations presented here define the scope in which the l.g.u. conducts activities related to the organisation of access to the guaranteed services. The legislator has adopted a method to identify the legal framework that directs the activities of the l.g.u. and rationalises the use of public funds. The key to ensuring the expediency of the actions taken is information, the quality and availability of which determines the effectiveness of the operation of the local government unit, understood as the ability to quickly secure access to the health needs of members of the community which are either in short supply or required, at a given time, in view of epidemiological factors,

In Article 12 of the Act on the Information System in Health Care, the scope of data that a remitter, including a l.g.u., may obtain - using the terminology of this Act - is specified. The SIM information system (medical information system) processes data, including personal data and individual medical data, in order to improve the availability of service recipients to

19 Journal of Laws of 2015, item 458.

20 Journal of Laws of 2018, item 469. 
healthcare services financed or co-financed from public funds; monitoring equal access to healthcare services financed or co-financed from public funds; making it possible for remitters and recipients of services to obtain information on healthcare services, both already provided and planned; to enable recipients or their statutory representatives to obtain information on the right to healthcare services, the amount of public funds spent on financing these services, the amount of health insurance contributions paid by them and medical certificates issued, referred to in Article 55, section 1 of the Act of 25 June 1999 on Cash Benefits from Social Insurance in Case of Sickness and Maternity; enabling recipients of services or their statutory representatives to submit representations specified by law; analysis of the flow of public funds intended to finance health care services; assessment by authorised entities of the demand for health care services and processing of data for the needs of medical records referred to in Article 19 of the Act on the Information System in Health Care. Pursuant to the Act on the Information System in Health Care remitters, including l.g.u. have access to data, including personal and individual medical data of service recipients and data concerning service providers, processed in the SIM, to the extent necessary for the performance of statutory tasks, and the right to download from the statistical-settlement module of data necessaryto account for the health care services provided. Local government units are entitled to access the data processed in the SIM with regard to the tasks performed by these entities, resulting from the regulations governing the tasks of local government in the area of public health. By the way, it is worth pointing out that the governors are entitled to access collective data processed in the SIM, to the extent necessary to perform the tasks specified in Articles 10 and 95a of the Act of 27 August 2004 on Health Care Services Financed from Public Funds, within the scope of their competencies. It should be noted that downloading data processed in the SIM by the remitter is free of charge.

\section{CONCLUSION}

The legal regulations on e-health presented above, in the context of the system principle chosen, make it possible to draw certain conclusions. The development of information technologies has entered the area of health 
care. The European Union, aware of the differences in the development of health care systems in the Member States and of its own primary law conditions, has based the issue of the "networking" of national information systems with regard to the data required for cross-border healthcare on the principle of voluntariness and the primacy of national regulations. At the European level, it seems essential to ensure the interoperability of information systems, in order to avoid technological exclusion of specific areas of Member States' operations and to direct the data stream towards obtaining data that enable it to operate efficiently on a European scale. The role of the Member State is to maintain an integral development of its own IT systems for the implementation of health policy, to increase the standard of health services provided and to include the widest possible range of suppliers-receivers of medical data, including l.g.u. pursuing their own health care tasks that are not contrary to the nation-wide tasks. Using the principle of subsidiarity as a guideline for the adoption of specific legal solutions, including those concerning health protection, it is necessary to postulate the development of regulations that will increase the access of l.g.u. to the organisation of the provision of health services for members of their communities on the basis of information technologies. In turn, the role of the state should focus on creating and monitoring a nationwide e-health network and including as many users as possible in that network. However, the organisational and time failure of national solutions and attempts to set up regional e-health platforms are at odds with this assumption ${ }^{21}$.

\section{REFERENCES}

Banaszak Bogusław. 2009. Constitution of the Republic of Poland. Commentary. Warsaw: C.H. Beck.

Dobek Agnieszka. 2008. "Subsidiarity principle in the jurisprudence of the Constitutional Court". "Państwo - koncepcje i zadania, Studia Erasmiana Wratislaviensia", Vol. III.

Gaddi Antonio, Fabio Capello, Marco Manca. 2013. eHealth, Care and Quality of Life. Springer Science \& Business Media.

21 See: https://www.dobreprogramy.pl/Nie-na-ezdrowie.-Przez-zaniedbania-rzadu-Polska-straci-setki-milionow-zlotych-z-unijnych-srodkow, News,67218.html 
Kowalska Iwona, Anna Mokrzycka. 2013. Namysły nad problemami polityki zdrowotnej globalnej - europejskiej - krajowej: księga jubileuszowa prof. dra hab. Cezarego W. Włodarczyka, Warsaw: Diffin.

Kulesza Michał. 1998. "Principle of subsidiarity as a key to the reform of the administrative system of Central and Eastern European countries (using Poland as an example)". (In:) Subsidiarity, Dariusz Milczarek (ed.), Warsaw: Centrum Europejskie Uniwersytetu Warszawskiego.

Montesquieu Charles. 1927. The Spirit of Laws, Book XXVI, Of Laws, as relative to the order of things on which they determine. Chapter II. Of Laws divine and human, Warsaw: F. Hoesick;

Tomasz Musialik. 2013. „Stosowanie zasady pomocniczości na gruncie traktatu z Lizbony”, Modern Management Review 4:147-148.

Pius XI. 1932. Encyclical on re construction of the social order on the 40th anniversary of the encyclical Rerum Novarum, translated by Bishop St. Okoniewski, Warsaw: Katolickie Towarzystwo Wydawnicze.

Popławska Ewa. 1998. "Effect of the principle of subsidiarity on system chan ges in Poland". (In:) Subsidiarity, Dariusz Milczarek (ed.), Warsaw: Centrum Europejskie Uniwersytetu Warszawskiego.

Spieker Manfred. 1995. "Subsidiarity principle: anthropological foundations and political consequences, Społeczeństwo", 1: 35-37.

Wrześniewska-Wal Iwona. 2016. „Zdrowie publiczne w regulacjach Unii Europejskiej”. „Postępy Nauk Medycznych”; 5: 322-326. 